\title{
Massive transfusion triggers in severe trauma: Scoping review*
}

\author{
Cristina Estebaranz-Santamaría \\ Ana María Palmar-Santos ${ }^{2}$ \\ Azucena Pedraz-Marcos²
}

Objective: to identify the predictive variables or the massive transfusion triggers in severely traumatized patients through the existing scales. Method: a review of the literature was carried out using the Scoping Review method across the electronic databases CINAHL, MEDLINE, LILACS, the Cochrane and IBECS libraries, and the Google Scholar search tool. Results: in total, 578 articles were identified in the search and the 36 articles published in the last ten years were included, of which 29 were original articles and 7 review articles. From the analysis, scales for massive transfusion and their predictive triggers were examined. Conclusion: the absence of universal criteria regarding the massive transfusion triggers in traumatized patients has led to the development of different scales, and the studies on their validation are considered relevant for the studies about when to initiate this strategy.

Descriptors: Blood Coagulation Disorders; Wounds and Injuries; Blood Transfusion; Resuscitation; Resuscitation; Emergency Medical Service.

\footnotetext{
* Paper extracted from doctoral dissertation, "Assesment and Resuscitation of major trauma. Massive Transfusion Triggers", presented to Universidad Autónoma de Madrid, Madrid, Spain.

1 Hospital Universitario La Paz, Madrid, Spain.

2 Universidad Autónoma de Madrid, Madrid, Spain.
}

\section{How to cite this article}

Estebaranz-Santamaría C, Palmar-Santos AM, Pedraz-Marcos A. Massive transfusion triggers in severe trauma: Scoping review. Rev. Latino-Am. Enfermagem. 2018;26:e3102. [Access + † + ] ; Available in: DOI: http://dx.doi.org/10.1590/1518-8345.2574.3102. month day year 


\section{Introduction}

Hemorrhage is the leading cause of potentially preventable death among trauma patients, and early intervention within the first 24 hours after the event takes place is critical in terms of survival(1-2). In this way, trauma injuries have become a public health problem, which may have an impact not only on mortality, but also on years of life lost in younger adults ${ }^{(3)}$.

Gradually, in the last decades, new strategies and protocols have been developed with the aim of preventing the so-called "lethal triad", with its components: acidosis, hypothermia and coagulopathy, caused by the great loss of blood ${ }^{(4-5)}$. In this context, aiming at its prevention and resolution, the Damage Control Surgery (DCS) emerged, which is exclusively used in the operating room and, over the years, it has evolved towards the concept of Damage Control Resuscitation (DCR), encompassing the out-of-hospital and hospital emergency areas ${ }^{(2,6-7)}$. Within the main strategies of the DCR, it is worth highlighting the so-called Massive Transfusion (MT), which consists of the administration of ten or more blood products (red blood cells, plasma and platelets) within the first 24 hours, according to the traditional concept ${ }^{(4,8-9)}$. Other authoritative definitions include four or more components within the first hour(10), or five or more components within the first four hours ${ }^{(11-13)}$.

The main advantage of the administration of MT in relation to the other strategies of the DCR, such as fluid therapy, is that it improves tissue oxygenation. For this reason, its early initiation is prioritized through the early transfer to a hospital center, although it is not a standardized procedure available in the out-ofhospital emergency itself $f^{(9,14)}$. Most importantly, MT has shown an increase in survival, a decrease in subsequent transfusion requirements and a decline in the average length of hospital stay(8,14-16).

However, not all severe traumatized patients will be the receivers of this strategy, so predicting the real need for MT is considered essential, and it may only be performed after assessing several clinical, analytical and anatomical parameters, which are described as predictors or "triggers" $(9,17)$. For their measurement and interpretation, scales combining different types of variables have been developed in order to achieve a high predictive value and increase their specificity. However, despite the diversity of scales investigated and the frequent validation studies, a consensus on the "triggers" of MT has not yet been established(7).
The objective of this study was to perform a scoping review to identify the clinical, physiological and anatomical predictive variables of massive transfusion, or triggers, in severely traumatized patients through the existing scales.

\section{Method}

The theoretical framework used for the scoping review was proposed in 2005 by two English authors ${ }^{(18)}$. This methodology uses an approach aiming at a narrative synthesis, which is ideal for comparing scientific articles and contemplates the following steps that were considered in the present study: 1) identification of the research question or questions; 2) identification of relevant studies; 3 ) selection of studies; 4) data extraction; 5) synthesis and report of results; and 6) dissemination ${ }^{(18-19)}$.

Starting with the first phase of this methodology, the research question from which the scoping review began was: What are the predictive variables or the triggers for initiating massive transfusion scales in traumatized patients? For its resolution, a second phase characterized by the identification of relevant studies was initiated through a main search carried out over several months, according to previous recommendations from experts on the search terms and appropriate databases for its development.

Thus, a search across the literature was carried out using the following electronic resources and databases: Cumulative Index to Nursing and Allied Health Literature (CINAHL), Medical Literature Analysis and Retrieval System Online (MEDLINE), Latin American Literature and Caribbean Health Sciences Literature (LILACS), Spanish Bibliographic Index of Health Sciences (IBECS), Cochrane Library and Google Scholar search tool, as shown in Figure 1. In these databases, combinations of the following concepts were used as search strategy: "Massive", "Transfusion", "Trauma", "Predict*" and the descriptors: "Wounds and Injuries", "Blood Transfusion", with the Boolean operators "and" and "or". Furthermore, in the databases in which the mentioned words were available, it was specified that those words appearing in the title and/or abstract fields were in English, Spanish, Portuguese or French. Regarding the years interval analyzed, it was decided to encompass the last ten years, including the current year of 2017, due to the contemporaneity of the massive transfusion, its continuous scientific interest, and the magnitude of the significant contributions on 
the research theme. In addition, some studies prior to the aforementioned date, resulting from the search, were initially analyzed because they were considered relevant for the understanding and development of predictive scales for massive transfusion.

For the selection of articles, in the third phase of the scoping review, original and review studies were included, considering both the areas related to the creation of scales and their subsequent validations, and the more specific investigations in which the triggers are analyzed individually, as well as other general concepts of massive transfusion.

To ensure that this set did not present biased results, making it difficult to extrapolate the conclusions to a specific population group, it was also crucial to adopt exclusion criteria for the final selection of articles and their eligibility. Those articles in which the population was pediatric or with non-traumatic MT etiology were excluded, although these populations were also receivers of the strategy.

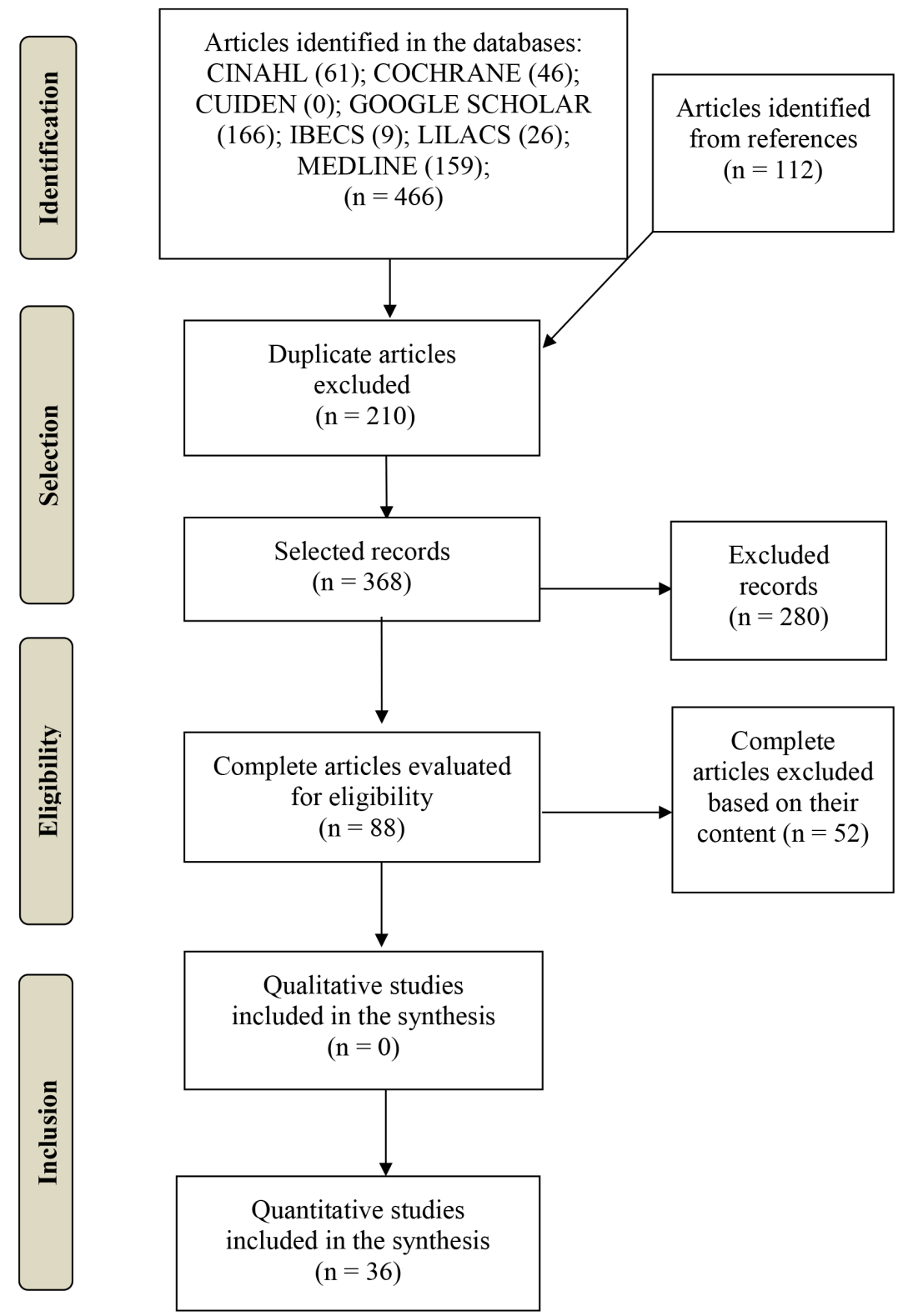

Figure 1. PRISMA flow diagram on the identification, selection and inclusion of articles. Madrid, Spain, 2017

In this way, 578 articles in total were obtained using the search strategy, of which 36 finally met the inclusion criteria. The distribution of the articles identified in the databases and the search and selection processes are illustrated in the flow diagram of Figure 1.
From the selected publications, the data corresponding to the fourth phase were extracted by a two phases analysis, beginning firstly with those studies that gave rise to the scales, being identified: general data (date and place), type of publication with its corresponding design 
type (prospective or retrospective), characteristics of the sample (incidence of MT), statistical results - sensitivity $(S)$, specificity $(E)$, Area Under the Curve (AUC), Odds Ratio (OR), positive predictive value (PPV) and negative predictive value (NPV) - and main conclusions. Secondly, other articles that aimed to validate the scales with other samples, analyze specific triggers in a particular way and review other concepts about MT were examined.

Finally, the phase of gathering and synthesis of the results was carried out with the main objective of presenting an overview of all the material, through a thematic construction organized for its subsequent dissemination phase. In this way, in this scoping review, both the original articles and the review articles were included in order to provide a detailed understanding of the issue to be analyzed, that is, the predictive variables or the massive transfusion triggers in severe trauma.

\section{Results}

Of the 36 studies identified based on their typology, 29 original and 7 review studies were selected, which were divided into two groups according to the methodology used for their development. Thus, the first group of results corresponds to the analysis of 19 of the 36 original studies on massive transfusion scales and their validation. In the second group are the 10 remaining studies, together with the 7 review articles, including the specific studies on the triggers and the general concepts about MT. Starting with the first group, the scales with their respective predictive clinical, physiological and anatomical variables, arranged chronologically according to their development and implementation, are presented below ${ }^{(20-37)}$ :

- Shock Index (SI): Systolic Blood Pressure (SBP), HR (Heart Rate) $)^{(20-21)}$.

- Emergency Transfusion Score (ETS): SBP, Focused Abdominal Sonography for Trauma (FAST), type of trauma, age and injury mechanism ${ }^{(22-23)}$.

- Trauma Associated Severe Hemorrhage (TASH): SBP, HR, Hemoglobin (Hb), Base excess (BE), FAST and trauma type (24-25).

- Schreiber: Hemoglobin (Hb), International Normalized Ratio (INR), trauma type and $\operatorname{sex}^{(26)}$.

- McLaughlin: SBP, HR, pH and Hematocrit (Hct)(27).

- Assessment of Blood Consumption (ABC): SBP, HR, FAST, trauma type ${ }^{(28-29)}$

- Larson: $\mathrm{SBP}, \mathrm{HR}, \mathrm{Hb}$ y $\mathrm{BE}^{(30)}$.

- Vandromme: SBP, HR, Hb, INR and Lactate(31).

- Prince of Wales Hospital (PWH/Rainer): SBP, HR, FAST, trauma type, Hb, BE and Glasgow Coma Scale (GCS) ${ }^{(5,32)}$.

- Cincinnati Individual Transfusion Trigger (CITT): $\mathrm{SBP}, \mathrm{T}, \mathrm{Hb}, \mathrm{BE}, \mathrm{INR}$ and FAST(33).

- Massive Transfusion Score (MTS) and Revised Massive Transfusion Score (RMTS): SBP, HR, T, $\mathrm{Hb}, \mathrm{BE}, \mathrm{INR}, \mathrm{FAST}$ and trauma type ${ }^{(34-35)}$.

- Traumatic Bleeding Severity Score (TBSS): SBP, Lactate, FAST, type and age ${ }^{(36-37)}$.

In this way, the statistical data described in them were reviewed in order to compare the samples and their results, among other aspects, according to Figures 2, 3, 4 and 5 .

\begin{tabular}{|c|c|c|c|c|}
\hline $\begin{array}{c}\text { Scale } \\
\text { and year }\end{array}$ & $\begin{array}{l}\text { Context } \\
\text { (country and } \\
\text { period) }\end{array}$ & $\begin{array}{l}\text { Area and type of } \\
\text { study }\end{array}$ & $\begin{array}{l}\text { Total: } \\
\text { MT** }^{*} \%\end{array}$ & Results and statistical data \\
\hline $\begin{array}{c}\mathrm{Sl}^{\dagger} \\
2016^{(20)}\end{array}$ & $\begin{array}{c}\text { China }(01 / 2009 \\
\text { to } 12 / 2014)\end{array}$ & $\begin{array}{l}\text { Emergency. Cohorts } \\
\qquad(\mathrm{R})^{\ddagger}\end{array}$ & 2490: $99,3.98 \%$ & $\begin{array}{l}\text { AUC\$, S"l, E": } \\
\text { SIt: }^{\top} .76,56.3 \%, 87.6 \% \\
\text { SI }^{\dagger} \text { (Modified):1.15, 61.5\%, 82.3\% } \\
\text { Modified comorbidity prediction }\end{array}$ \\
\hline $\begin{array}{c}\mathrm{Sl}^{\dagger} \\
2016^{(21)}\end{array}$ & $\begin{array}{l}\text { France } \\
(01 / 2009 \text { to } \\
12 / 2011)\end{array}$ & $\begin{array}{l}\text { Emergency. } \\
\text { Cohorts } \\
(R)^{\ddagger}\end{array}$ & 2557: $176,6.9 \%$ & $\begin{array}{l}\text { AUCs, } S^{\prime \prime}, E^{\pi:} \\
3 \text { hours: } 0.72,53 \%, 85 \% \\
24 \text { hours: } 0.967,68 \%, 86 \%\end{array}$ \\
\hline $\begin{array}{l}\text { ETS }^{* *} \\
2006^{(22)}\end{array}$ & $\begin{array}{l}\text { Germany } \\
(05 / 1998 \text { to } \\
01 / 2002)\end{array}$ & $\begin{array}{l}\text { Emergency. } \\
\text { Cohorts }(P)^{++}\end{array}$ & $\begin{array}{c}\text { 1.103: } 116 \\
10.52 \%\end{array}$ & $\begin{array}{l}\text { OR } \\
\text { Blood pressure }<90 \rightarrow 12.2 \\
\text { Positive FAST } \rightarrow 8.4 \\
\text { Score and prediction: } \\
<3:<5 \% \mathrm{MT}^{*}(10) \\
=3: 5-10 \% \mathrm{MT}^{\star}(9) \\
>3:>10 \% \mathrm{MT}^{\star}(87)\end{array}$ \\
\hline $\begin{array}{l}\text { ETS }^{* *} \\
2008^{(23)}\end{array}$ & $\begin{array}{l}\text { Germany } \\
(07 / 2003 \text { to } \\
12 / 2004)\end{array}$ & $\begin{array}{l}\text { Emergency. } \\
\text { Cohorts }(P)^{+\dagger}\end{array}$ & $\begin{array}{c}481: 40 \\
8.32 \%\end{array}$ & $\begin{array}{l}\text { S"I, Eđ, PPV\$S, NPVIII: } \\
\geq 3: 97.5 \%, 68 \%, 22.2 \%, 99.7 \% \\
\geq 2: 100 \% 42.2 \%, 11.5 \%, 100 \% \\
\geq 4: 84.2 \%, 92.5 \%, 31.4 \%, 98.4 \%\end{array}$ \\
\hline
\end{tabular}

(the Figure 2 continue in the next page...) 


\begin{tabular}{|c|c|c|c|c|}
\hline $\begin{array}{c}\text { Scale } \\
\text { and year }\end{array}$ & $\begin{array}{c}\text { Context } \\
\text { (country and } \\
\text { period) }\end{array}$ & $\begin{array}{l}\text { Area and type of } \\
\text { study }\end{array}$ & $\begin{array}{l}\text { Total: } \\
\text { MT*, \% }\end{array}$ & Results and statistical data \\
\hline $\begin{array}{l}\text { TASH"Tा } \\
2006^{(24)}\end{array}$ & $\begin{array}{c}\text { Germany } \\
\text { (1993 to 2003) }\end{array}$ & $\begin{array}{l}\text { Emergency. } \\
\text { Cohorts }(\mathrm{P})^{++}\end{array}$ & $\begin{array}{c}6044: 855,14.1 \% \\
\text { a) } 4527: 623 \\
\text { b) } 1517: 218\end{array}$ & $\begin{array}{l}\text { AUCs: } 0.893, \mathrm{Sll}^{\|}: 41 \%, \mathrm{E}^{\top}: 97 \% \\
\text { Score and prediction: } \\
=16: 50 \% \mathrm{MT}^{*} \\
\geq 27: 100 \% \mathrm{MT}^{*} \\
\text { It was found that Temperature and } \mathrm{pH} \text { are not regularly } \\
\text { registered }\end{array}$ \\
\hline $\begin{array}{l}\text { TASH }{ }^{\pi \pi} \\
2011^{(25)}\end{array}$ & $\begin{array}{c}\text { Germany } \\
\text { (2004 to 2007) }\end{array}$ & $\begin{array}{l}\text { Emergency. } \\
\text { Cohorts }(P)^{+t}\end{array}$ & 5834: $490,8.4 \%$ & $\begin{array}{l}\text { AUCs: } 0.905, S^{\|}: 45 \%, E^{\Uparrow:}: 97 \% \\
\text { Other values that do not change the accuracy are } \\
\text { registered: INR, lactate, trauma type and accident, } \mathrm{pH} \text {, } \\
\text { temperature }\end{array}$ \\
\hline $\begin{array}{l}\text { Schreiber } \\
2007^{(26)}\end{array}$ & Iraq & $\begin{array}{l}\text { Hospitals combat } \\
\text { Cohorts. }(R)^{\ddagger}\end{array}$ & $\begin{array}{c}\text { 558: } 247, \\
44.3 \%\end{array}$ & $\begin{array}{l}\text { AUCs: } 0.804 \\
\text { OR } \\
\text { Hemoglobin } \leq 11 \rightarrow 7.7 \\
\text { INR> } 1.5 \rightarrow 5.9 \\
\text { Trauma: penetrating } \rightarrow 2.6\end{array}$ \\
\hline
\end{tabular}

*MT - Massive Transfusion, +SI - Shock Index, $\neq(\mathrm{R})$ - Retrospective, §AUC - Area Under the Curve, IIS - Sensitivity, ףE - Specificity, **ETS - Emergency

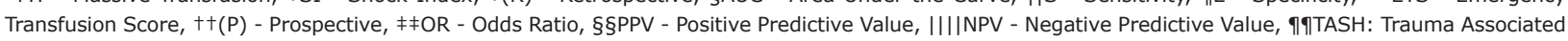
Severe Hemorrhage

Figure 2. Characteristics of the studies on Shock Index (SI), Emergency Transfusion Score (ETS), Trauma Associated Severe Hemorrhage (TASH) and Schreiber. Madrid, Spain, 2017

\begin{tabular}{|c|c|c|c|c|}
\hline $\begin{array}{l}\text { Scale } \\
\text { and year }\end{array}$ & $\begin{array}{l}\text { Context (country } \\
\text { and period) }\end{array}$ & $\begin{array}{l}\text { Area and type of } \\
\text { study }\end{array}$ & $\begin{array}{c}\text { Total: } \text { MT }^{*}, \\
\%\end{array}$ & Results and statistical data \\
\hline $\begin{array}{c}\text { Mc } \\
\text { Laughlin } \\
2008^{(27)}\end{array}$ & $\begin{array}{c}\text { USA }(09 / 2003 \text { to } \\
12 / 2004)\end{array}$ & $\begin{array}{l}\text { Hospitals combat. } \\
\text { Cohorts } \\
(\mathrm{R})^{\dagger}\end{array}$ & $\begin{array}{l}302: 80 \\
26.5 \%\end{array}$ & 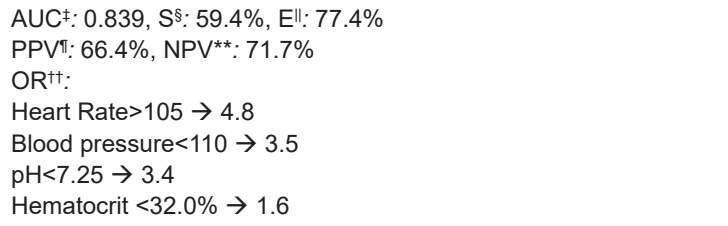 \\
\hline $\begin{array}{l}A B C^{\ddagger \ddagger} \\
2009^{(28)}\end{array}$ & $\begin{array}{c}\text { USA }(07 / 2005 \text { to } \\
06 / 2006)\end{array}$ & $\begin{array}{c}\text { Emergency. } \\
\text { Cohorts } \\
(\mathrm{R})^{\dagger}\end{array}$ & $\begin{array}{l}\text { 596: } 76 \\
12.7 \%\end{array}$ & $\begin{array}{l}\text { AUC:: } 0.842, S^{\S}, E^{\|}: \\
\text {1: } 95 \%, 56 \% \\
\geq 2: 75 \%, 86 \% \\
\geq 3: 25 \%, 97 \% \\
\geq 4: 6 \%, 100 \%\end{array}$ \\
\hline \multirow{4}{*}{$\begin{array}{l}A B C^{\ddagger \ddagger} \\
2010^{(29)}\end{array}$} & \multirow{4}{*}{$\begin{array}{c}\text { USA }(07 / 2006 \text { to } \\
06 / 2007)\end{array}$} & \multirow{4}{*}{$\begin{array}{l}\text { Emergency. } \\
\text { Cohorts } \\
(\mathrm{R})^{\dagger}\end{array}$} & $\begin{array}{c}\text { 513: } 72 \\
14 \%\end{array}$ & 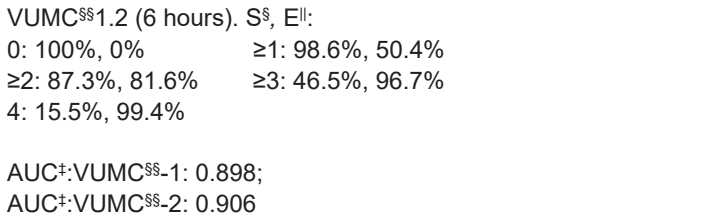 \\
\hline & & & $\begin{array}{l}\text { 513: } 72 \\
14 \%\end{array}$ & 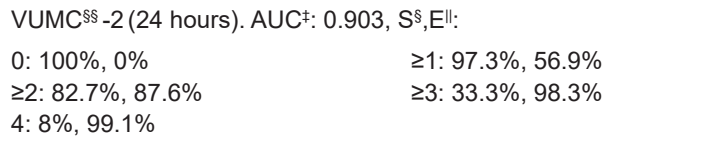 \\
\hline & & & $\begin{array}{c}372: 56 \\
15 \%\end{array}$ & 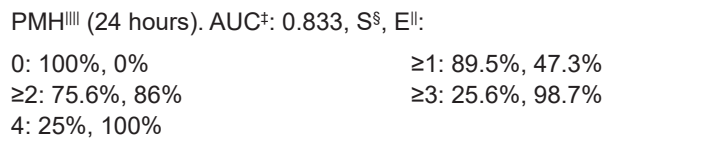 \\
\hline & & & $\begin{array}{c}\text { 133: } 19 \\
14 \%\end{array}$ & 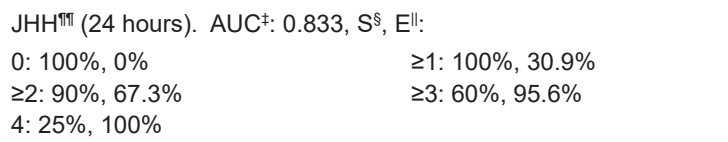 \\
\hline $\begin{array}{l}\text { Larson } \\
2010^{(30)}\end{array}$ & $\begin{array}{c}\text { USA }(03 / 2003 \text { to } \\
06 / 2008)\end{array}$ & $\begin{array}{l}\text { Hospital combat. } \\
\text { Cohorts }(R)^{\dagger}\end{array}$ & $\begin{array}{c}\text { 1124: } 420 \\
37 \%\end{array}$ & $\begin{array}{l}\text { Results considering at least two variables (Heart Rate }>110 \text {, Blood } \\
\text { Pressure<110, Base Excess } \leq-6 \text {, Hemoglobin<11): } \\
\text { S§: } 69 \% \text {, Ell: } 65 \% \\
\text { PPVT: } 54 \% \text {, NPV**: } 78 \%\end{array}$ \\
\hline
\end{tabular}

$*$ MT - Massive Transfusion, †(R) - Retrospective, $¥$ AUC - Area Under the Curve, §S - Sensitivity, ||E - Specificity, \PPV - Positive Predictive Value, **NPV - Negative Predictive Value, †+OR - Odds Ratio, $\neq \neq A B C$ - Assessment of Blood Consumption, §§VUMC - Vanderbilt University Medical Center, IIIIPMH Parkland Memorial Hospital, 凤ๆJHH - Johns Hopkins Hospital

Figure 3. Characteristics of the studies on McLaughlin, Assessment of Blood Consumption (ABC) and Larson. Madrid, 


\begin{tabular}{|c|c|c|c|c|}
\hline $\begin{array}{l}\text { Scale } \\
\text { and year }\end{array}$ & $\begin{array}{l}\text { Context (country } \\
\text { and period) }\end{array}$ & $\begin{array}{l}\text { Area and type of } \\
\text { study }\end{array}$ & Total: $\mathbf{M T}^{*}, \%$ & Results and statistical data \\
\hline $\begin{array}{l}\text { Vandromme } \\
2011^{(31)}\end{array}$ & $\begin{array}{c}\text { USA }(01 / 2005 \text { to } \\
12 / 2008)\end{array}$ & $\begin{array}{l}\text { Emergency } \\
\text { Cohorts } \\
(\mathrm{R})^{\dagger}\end{array}$ & $\begin{array}{c}\text { 6638: } 158 \\
2.4 \%\end{array}$ & $\begin{array}{l}\text { Presence of three or more variables: } \\
\text { AUCः: } 0.9, S^{\S}: 53 \%, E^{\|}: 98 \% \\
\text { PPVI: } 33 \%, \text { NPV**: }^{*} \%\end{array}$ \\
\hline $\begin{array}{c}\mathrm{PWH}^{++} \text {Score } \\
2011^{(32)}\end{array}$ & $\begin{array}{c}\text { China }(01 / 2001 \text { to } \\
08 / 2009)\end{array}$ & $\begin{array}{l}\text { Emergency } \\
\text { Cohorts } \\
(\mathrm{R})^{\dagger}\end{array}$ & 4336: $92,2,12 \%$ & $\begin{array}{l}\text { AUC:: } 0.889, S^{\S}: 31.5 \%, \text { El: } 99.7 \% \\
\text { PPVI: } 82.9 \%, \text { NPV }{ }^{* *}: 96.6 \% \\
\text { Score } \geq 6, O R^{ \pm \pm}: \\
\text {Blood pressure } \leq 90 \rightarrow 9.0 \\
\text { FAST positive } \rightarrow 7.0 \\
\text { Glasgow Coma Scale } \leq 8 \rightarrow 2.0 \\
\text { Pelvic fracture } \rightarrow 4.1 \\
\text { Heart Rate } \geq 120 \rightarrow 3.2 \\
\text { Base Excess } \geq 5 \rightarrow 4.8 \\
\text { Hemoglobin } \leq 7 \rightarrow 45.7 / / 7-10 \rightarrow 2.8\end{array}$ \\
\hline $\begin{array}{c}\mathrm{PWH}^{++} \text {Score } \\
2012^{(5)}\end{array}$ & $\begin{array}{l}\text { Australia }(01 / 2006 \\
\quad \text { to } 12 / 2009)\end{array}$ & $\begin{array}{l}\text { Emergency } \\
\text { Cohorts } \\
(\mathrm{R})^{\dagger}\end{array}$ & $\begin{array}{c}\text { 1234: } 195 \\
15,8 \%\end{array}$ & 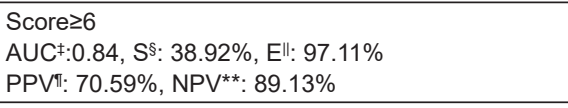 \\
\hline 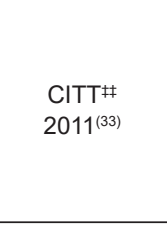 & $\begin{array}{c}\text { USA }(10 / 2007 \text { to } \\
09 / 2008)\end{array}$ & $\begin{array}{c}\text { Emergency } \\
\text { (Emergency Surgery). } \\
\text { Cohorts } \\
(\mathrm{R})^{\dagger}\end{array}$ & $\begin{array}{l}\text { 170: } 77,45 \% \\
\text { transfu-sion }\end{array}$ & 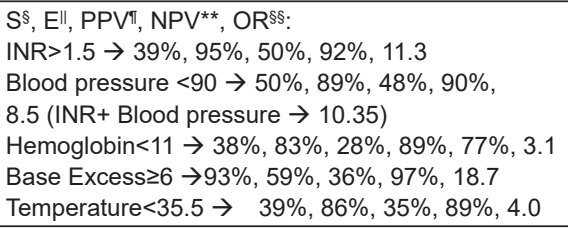 \\
\hline $\begin{array}{l}\text { MTSIIII } \\
2013^{(34)}\end{array}$ & $\begin{array}{l}\text { USA } 07 / 2009 \\
\text { to } 10 / 2010 \text { ) }\end{array}$ & $\begin{array}{l}\text { Emergency } \\
\text { Cohorts }(\mathrm{P})^{\pi / 1}\end{array}$ & 1245: $297,24 \%$ & 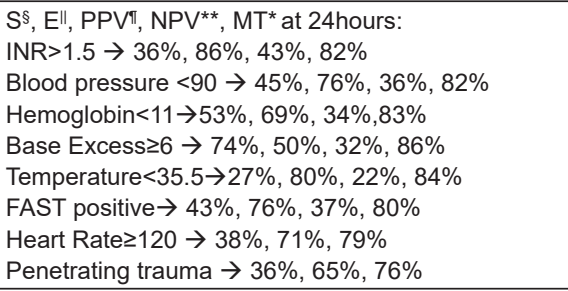 \\
\hline
\end{tabular}

*MT - Massive Transfusion, +(R) - Retrospective, ¥AUC - Area Under the Curve, §S - Sensitivity, I|E - Specificity, ๆPPV - Positive Predictive Value, **NPV -

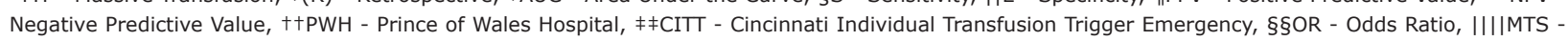
Massive Transfusion Score,

Figure 4. Characteristics of the studies on Vandromme, Prince of Wales Hospital (PWH) Score, Cincinnati Individual Transfusion Trigger Emergency (CITT) and Massive Transfusion Score (MTS). Madrid, Spain, 2017

\begin{tabular}{|c|c|c|c|c|}
\hline $\begin{array}{c}\text { Scale } \\
\text { and year }\end{array}$ & $\begin{array}{l}\text { Context (country } \\
\text { and period) }\end{array}$ & $\begin{array}{l}\text { Area and type of } \\
\text { study }\end{array}$ & $\begin{array}{l}\text { Total: } \\
\text { MT*, \% }\end{array}$ & Results and statistical data \\
\hline $\begin{array}{l}\text { RMTS }^{\dagger} \\
2016^{(35)}\end{array}$ & $\begin{array}{c}\text { USA } \\
\text { (2005 to 2011) }\end{array}$ & $\begin{array}{l}\text { Emergency. } \\
\text { Cohorts } \\
(P)^{\ddagger}\end{array}$ & 190 & 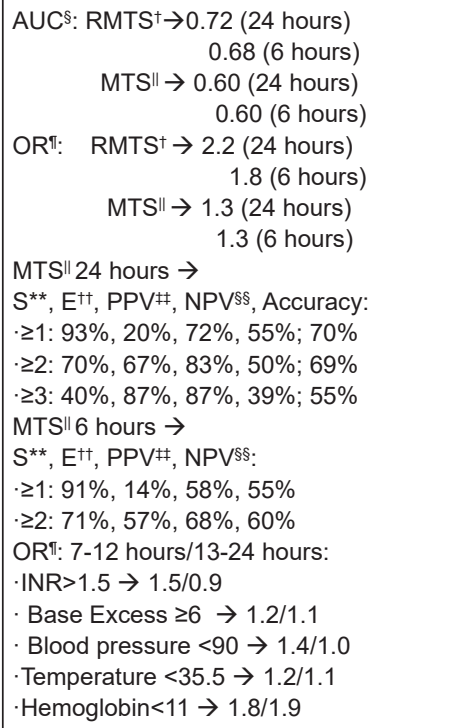 \\
\hline $\begin{array}{l}\text { TBSS'IIII } \\
2014^{(36)}\end{array}$ & $\begin{array}{c}\text { Japan } \\
\text { Development }(01 / 2008 \\
\text { to } 12 / 2009) \\
\text { Validation }(01 / 2010 \text { to } \\
03 / 2012)\end{array}$ & $\begin{array}{l}\text { Emergency. } \\
\text { Cohorts }(R)^{\pi \pi}\end{array}$ & $\begin{array}{c}\text { Development 119: } 62 \\
\text { Validation total: } 113\end{array}$ & $\begin{array}{l}\text { Score } \geq 15 \\
\text { AUC§: } 0.985, \\
S^{* *}: 97.4 \%, E^{+1}: 96.2 \%\end{array}$ \\
\hline
\end{tabular}




\begin{tabular}{|c|c|c|c|c|}
\hline $\begin{array}{l}\text { Scale } \\
\text { and year }\end{array}$ & $\begin{array}{l}\text { Context (country } \\
\text { and period) }\end{array}$ & $\begin{array}{l}\text { Area and type of } \\
\text { study }\end{array}$ & $\begin{array}{l}\text { Total: } \\
\text { MT* } \%^{*}\end{array}$ & Results and statistical data \\
\hline $\begin{array}{l}\text { TBSSIIII } \\
2016^{(37)}\end{array}$ & $\begin{array}{c}\text { Japan } \\
(01 / 2010 \text { a 03/2014) }\end{array}$ & $\begin{array}{l}\text { Emergency. } \\
\text { Cohorts }(R)^{\text {nTा }}\end{array}$ & $300: 84,28 \%$ & 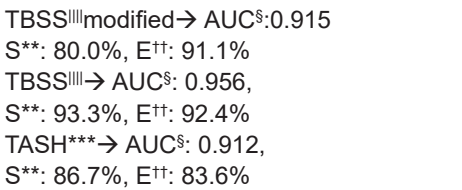 \\
\hline
\end{tabular}

*MT - Massive Transfusion, +RMTS - Revised Massive Transfusion Score, ¥(P) - Prospective, §AUC - Area Under the Curve, IIMTS - Massive Transfusion Score, ๆOR - Odds Ratio, **S - Sensitivity, ††E - Specificity, ‡¥PPV - Positive Predictive Value, §§NPV - Negative Predictive Value, IIIITBSS - Traumatic Bleeding Severity Score, ११(R) - Retrospective, ***TASH - Trauma Associated Severe Hemorrhage

Figure 5. Characteristics of the studies on Revised Massive Transfusion Score (RMTS) and Traumatic Bleeding Severity Score (TBSS). Madrid, Spain, 2017

As can be observed in Figures 2, 3, 4 and 5, of the 19 studies included that have led to the development scales for MT, most were conducted in the USA (8), followed by Germany (4) and Japan (2), and they were divided in two groups: those of retrospective nature (13) and those prospective in nature (6). In addition, except for three studies, their scope of analysis included the civilian population and they were performed in Emergency Hospitals (16), except for those carried out in Combat Hospitals (3). This characteristic directly influences the results, since the incidence of MT is altered. In these latter, higher percentages of MT are observed (between $26.5 \%$ and $44.5 \%$ among all traumatized patients), and lower percentages are observed in those conducted with a civilian population (between $2.12 \%$ and $28 \%$ ).

\section{Statistical data from scales}

Regarding the AUC, sensitivity, specificity, OR, NPV and PPV, the studies report different percentages associated with the cut-off points established in each scale, with a higher value corresponding to a higher prediction of MT. Considering the AUC as reference, the three scales with the highest values are $\operatorname{TBSS}^{(36-37)}(0.985$ and 0.956$), \operatorname{TASH}^{(25,37)}(0.912$ and 0.905$)$ and $A B C^{(29)}$ (0.906 at $6 \mathrm{~h}$ and 0.903 at $24 \mathrm{~h})$. As for sensitivity, the TBSS $^{(36-37)}$ shows higher values $(97.4 \%, 93.3 \%)$ when compared to other scales, such as the $\operatorname{TASH}^{(37)}(86.7 \%)$ and the $\operatorname{RMTS}^{(35)}$ ( $91 \%$ at $6 \mathrm{~h}$ and $93 \%$ at $24 \mathrm{~h}$ ). Regarding the specificity, higher values were achieved in the $\mathrm{PWH}^{(5,32)}$ (99.7\% and $97.11 \%)$ and Vandromme ${ }^{(31)}(98 \%)$, followed by the $\operatorname{TASH}^{(24-25,37)}(97 \%, 83.6 \%)$ and the TBSS(36-37) $(96.2 \%, 92.4 \%)$. In general, most of them describe high NPVs, thus avoiding the undertriage of patients, generally exceeding $90 \%$, as in the cases of the Vandromme ${ }^{(31)}$ (99\%), PWH(32) (96.6\%) and $\operatorname{ETS}^{(23)}(98.4 \%)$. As can be seen in Figures 3, 4 and 5, in some studies, NPVs are associated with individual triggers, but not with the whole scale, as with the $\mathrm{OR}$, and it is highlighted the

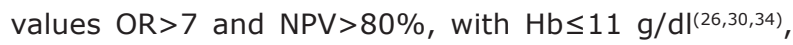
FAST positive ${ }^{(32-34)}, \mathrm{SBP} \leq 90 \mathrm{mmHg}{ }^{(32-34)}, \mathrm{INR}>1.5^{(33-34)}$ and $B E \geq 6^{(33-34)}$. Finally, the PPVs corresponding to a more accurate prediction of MT are the upper scores in the scales RMTS $\geq 3$ at 24 hours $^{(35)}(87 \%), \mathrm{PWH} \geq 6^{(5)}$ (70.59\%), McLaughlin(27) $(66.4 \%)$, and when there are two positive variables in $\operatorname{Larson}^{(30)}(54 \%)$.

\section{Complementary studies}

Furthermore, as mentioned above, in this scoping review 17 other articles were included to obtain a more detailed understanding of the study theme. Thus, other researches with comparative assessments between the scales for MT and the specific analyzes on the clinical and physiological predictive triggers were identified, which consisted of 10 original and 7 review studies.

By comparing it with a validation study of the RMTS(35) that describes an AUC in the RMTS (0.68 at $6 \mathrm{~h}$ and 0.72 at $24 \mathrm{~h})$ higher than that in the $A B C(0.58$ at $6 \mathrm{~h}$ and 0.51 at $24 \mathrm{~h}$ ) of other studies ${ }^{(38)}$, it is observed that this latter scale is superior in terms of sensitivity (75\%) and NPV (97\%). Similarly, PWH is considered a useful scale with high specificity (99.7\%) and PPV (82.9\%), in comparison with the other the scales ${ }^{(38)}$. Moreover, after a revision of the literature, other acceptable AUCs of about 0.89 were described for the TASH(20-21,39), $\mathrm{PWH}^{(38-39)}$ and $A B C^{(21)}$. Finally, other scales such as Schreiber are highlighted for their sensitivity $(85.8 \%)$, Larson for its specificity (80.4\%) and TASH for its PPV (18.9\%) and NPV $(98.8 \%)$, in studies with other samples and settings ${ }^{(39)}$.

\section{Definition of Massive Transfusion}

One aspect that must be highlighted is that, most of the studies included for the selection of patients for MT, consider the administration of $\geq 10$ Units at 24 
hours ${ }^{(40-41)}$, although other intervals are also analyzed in some of them for obtaining the sample. Among these thresholds is the Critical Administration Threshold (CAT) that is defined as the administration of $\geq 3$ units at 1 hour ${ }^{(21,42-43)}$, and others, such as $\geq 4$ units at 4 hours $^{(41,44)}$, $\geq 5$ units at 4 hours $^{(45)}$ or at 6 hours(29,34-35,46). Other tendencies have been found, which describe the patient as belonging to the MT group when there are blood requests without cross-matching, or blood group 0 , as this has been identified as a good predictor for initiating the MT strategy $(35,38,41,44,47)$.

\section{Specific triggers}

In addition to the research studies on the scales, other studies examine the triggers at the individual level. In a study carried out last year, the continuous monitoring of patient's vital signs was carried out on their arrival at the hospital, through the measuring of $\mathrm{HR}$ and SBP, in order to associate them with MT prediction. It was concluded that at 10-15 minutes of their arrival these variables were significant in that field of study ${ }^{(41)}$. Another widely studied variable is $\mathrm{Hb}$, whose scale range varies, being considered as a positive trigger when its values are lower than $11 \mathrm{~g} / \mathrm{dl}^{(24-26,30,33-35)}$, although some more critical values, below 7, have been considered ${ }^{(24-25,38)}$, so there is not a specific value associated with a decrease in mortality, and it may oscillate between the two figures mentioned(48).

Regarding the study on other triggers, temperature is usually not evaluated ${ }^{(25,34)}$ although it is considered as relevant in some studies ${ }^{(33,35)}$, and the INR has a high predictive value if $\geq 1.5^{(26,33-35)}$, as well as the presence of penetrating trauma mechanism and FAST positive(22,32-37).

The new tendencies report Fibrinogen and $\mathrm{BE}^{(46,49-50)}$ as individual predictors of MT, which stand out because they diminish early, even before the other coagulation factors $^{(49)}$. The prothrombin time (PT) and the activated partial thromboplastin time (aPTT) ${ }^{(46,51)}$, among others, used to determine Acute Traumatic Coagulopathy (ATC) are examined using the PROMMTT sample(52) and its subsequent investigations ${ }^{(34,46,53)}$, which show their alteration but do not determine a fixed interval with regard their definition.

Finally, there is a clear need for a MT protocol or universal $\mathrm{DCR}^{(41,54)}$, since both the mortality of the traumatized patient and the need for blood units during hospitalization can be reduced through the unification of criteria and strategies of action.

\section{Discussion}

The MT strategy has a low incidence in the total population, but its repercussions bring with it a large amount of material, personal and organizational health resources ${ }^{(1,4,6,8,15-16,41)}$. This incidence, described in the studies included in the review and expressed as percentage in relation to the traumatized population, will depend on the sphere where the sample was collected and the inclusion criteria used(20-37). Despite this discrepancy, the receivers of MT do not usually exceed $15 \%{ }^{(28-29,31-32,38-39,41-44)}$.

From these results, a particular and general analysis of all predictive scales for MT and their triggers is obtained, and it is possible to identify two subgroups of variables, the clinical and the analytical ones. Thus, those authors who only use clinical variables as triggers, regardless of the laboratory values ${ }^{(20-22,24)}$, justify their decision based on the need to perform MT early, and argue that an analysis of such variables would cause a delay in the administration of units because of their complex calculations ${ }^{(32,40)}$ and the use of non-immediate complementary tests( ${ }^{(36-37,40)}$. However, when the results accuracy with the scales that combine the two types of triggers is taken into account, there is a significant improvement in the effectiveness of this decision, despite the later start of the strategy, as with the scales ABC, TASH and TBSS(24-25,28-29,36-37).

Similarly, in spite of the high values described in the TASH and ABC, in terms of specificity, they have low sensitivity and lead to undertriage in many occasions. However, they are considered acceptable by some authors $(38,40)$ when they show high NPVs, because if such a situation occur and the protocol is activated and, ultimately, it is no longer necessary, there would be the possibility of returning the requested blood products back to the Blood Bank.

As regards to the triggers investigated at the individual level, Hemoglobin is part of most studies, but there is no consensus on its critical range for activating the MT protocol(24-26,30,32-35,38-39,48). A possible explanation is that it varies depending on the moment in which the analytical value is obtained, influencing both the time elapsed since the incident and the strategies performed before obtaining the first sample ${ }^{(48)}$.

Regarding the concept of massive transfusion, a variation in its definition has been observed, which it is coincident with the chronological progression over the years. Thus, in more recent studies, MT triggers are 
usually analyzed more frequently in the early hours, between one and four hours, since the critical level of the individual is higher at that period(21,41-44).

As a main limitation found, it can be highlighted that in many studies the need for MT itself is not described, but the use of this strategy $y^{(35,41)}$. That is, it is difficult to differentiate between those who really need MT and those who receive it. Similarly, the samples and environments used in the studies are not equivalent or easily comparable, except for those that are carried out by the same research group or arise from the same selection of patients as, for example, in the MTS ${ }^{(34-35,52)}$.

Finally, the need to use scales arises from the presence of atypical or not apparent hemorrhages, since there is no doubt on how to proceed when there are external bleeds. In addition to all this, the fact that not all health personnel are specialized in the care for the traumatized patient would lead to a disparity of criteria, since there is in the same Hospital Emergency a large number of professionals involved in their care, with different profiles and types of residences ${ }^{(41)}$. Therefore, with the implementation or use of the same scale, both the team's work and the quality of care provided could be facilitated with the application of the same protocol.

\section{Conclusion}

The variability of universal criteria regarding the massive transfusion triggers in traumatized patients has led to the creation of different scales. Therefore, the validation studies of these scales are relevant to reach an agreement about the criteria on when to initiate this strategy.

Therefore, the conclusions of this scoping review, based on the characteristics of the selected studies, can be summarized as they are quantitative, predominantly retrospective in nature and focused on a single care field: the emergency hospital. This arises the need to propose the development of new research studies, in which the different scales and the massive transfusion triggers are analyzed in the two initial critical care areas for the subjects described, the hospital emergency and the out-of-hospital emergency, using the same sample.

However, this review is considered useful not only in the research field, but also in the care field, since it compares the existing scales for massive transfusion and their main conclusions, aiming at reaching a common protocol of action for urgency and emergency health personnel. Thus, by establishing this continuity, it would be possible to follow the massive transfusion triggers and the pertinence of initiating this strategy, identifying the areas for potential improvement, and proposing a further formation on massive transfusion and severely traumatized patients.

\section{References}

1. Spahn DR, Bouillon B, Cerny V, Coats TJ, Duranteau J, Fernández-Mondéjar $E$, et al. Management of bleeding and coagulopathy following major trauma: an updated European guideline. Crit Care. 2013; 17(2):1-45. doi: http://dx.doi.org/10.1186/cc12685.

2. Henriksen HH, Rahbar E, Baer LA, Holcomb JB, Cotton BA, Steinmetz J, et al. Pre-hospital transfusion of plasma in hemorrhaging trauma patients independently improves hemostatic competence and acidosis. Scand J Trauma Resusc Emerg Med. 2016; 24(1):145. doi: http://dx.doi.org/10.1186/s13049-016-0327-z.

3. Organización Mundial de la Salud (OMS). Estadísticas Sanitarias Mundiales. Ginebra, Suiza: OMS; [Internet] 2014 [Acceso 20 jun 2016]. Disponible en: http://apps.who.int/iris/ bitstream/10665/131953/1/9789240692695_spa.pdf.

4. Spinella P, Holcomb JB. Resuscitation and transfusion principles for traumatic hemorrhagic shock. Blood Rev. 2009; 23(6):231-40. doi: http://dx.doi.org/10.1016/j. blre.2009.07.003.

5. Mitra B, Rainer TH, Cameron RA. Predicting massive blood transfusion using clinical scores post-trauma. Vox Sang. 2012; 102(4):324-30. doi: http://dx.doi. org/10.1111/j.1423-0410.2011.01564.x.

6. Le Noël A, Mérat $S$, Ausset $S$, De Rudnicki $S$, Mion G. Le concept de damage control resuscitation. Annales Françaises d'Anesthésieet de Réanimation. 2011; 30(9):665-78. doi: http://dx.doi.org/10.1016/j. annfar.2011.05.016.

7. Pohlman TH, Walsh M, Aversa J, Hutchison EM, Olsen $K P$, Reed RL. Damage control resuscitation. Blood Rev. 2015; 29(4):251-62. doi: http://dx.doi.org/10.1016/j. blre.2014.12.006.

8. Khan S, Allard S, Weaver A, Barber C, Davenport R, Brohi K. A major haemorrhage protocol improves the delivery of blood component therapy and reduces waste in trauma massive transfusion. Injury, Int ] Care Injured. 2013; 4(5):587-92. doi: http://dx.doi.org/10.1016/j. injury.2012.09.029.

9. Estebaranz Santamaría C, Palmar Santos AM, Pedraz Marcos A. Valoración y reanimación del trauma grave: triggers de transfusión masiva. NURE Invest. [Internet]. 2017 [Acceso 8 Ago 2017]; 14(88). Disponible en: 
http://www.nureinvestigacion.es/OJS/index.php/nure/ article/view/1002.

10. Phaml HP, Shazl BH. Update in massive transfusion. J Trauma Acute Care Surg. 2014; 76(6):1379-85. doi: http://dx.doi.org/10.1093/bja/aet376.

11. Mitra B, Cameron PA, Gruen RL, Mori A, Fitzgerald $M$, Street $A$. The definition of massive transfusion in trauma: a critical variable in examining evidence for resuscitation. Eur J Emerg Med. 2011; 18(3):137-42. doi: http://dx.doi.org/10.1097/MEJ.0b013e328342310e. 12. Zatta AJ, McQuilten ZK, Mitra B, Roxby DJ, Sinha R, Whitehead $S$, et al. Elucidating the clinical characteristics of patients captured using different definitions of massive transfusion. Vox Sang. 2014; 107(1):60-70. doi: http:// dx.doi.org/10.1111/vox.12121.

13. Olaussen A, Peterson EL, Mitra B, O'Reilly G, Jennings PA, Fitzgerald M. Massive transfusion prediction with inclusion of the pre-hospital Shock Index. Injury, Int J Care Injured. 2015; 46(5):822-6. doi: http:// dx.doi.org/10.1016/j.injury.2014.12.009.

14. Meyer DE, Vincent LE, Fox EE, O'Keeffe T, Inaba K, Bulger $E$, et al. Every minute counts: Time to delivery of initial massive transfusion cooler and its impact on mortality. J Trauma Acute Care Surg. 2017; 83(1):19-24. doi: http://dx.doi.org/10.1097/TA.0000000000001531. 15. Nardi G, Agostini V, Rondinelli B, Russo E, Bastianini $B$, Bini G, et al. Trauma-induced coagulopathy: impact of the early coagulation support protocol on blood product consumption, mortality and costs. Crit Care. 2015; 19(83):1-10. doi: http://dx.doi.org/10.1186/s13054015-0817-9.

16. Brown JB, Sperry JL, Fombona A, Billiar TR, Peitzman AB, Guyette FX. Pre-Trauma Center Red Blood Cell Transfusion Is Associated with Improved Early Outcomes in Air Medical Trauma Patients. J Am Coll Surg. 2015; 220(5):797-808. doi: http://dx.doi.org/10.1016/j. jamcollsurg.2015.01.006.

17. Rossaint R, Bouillon B, Cerny V, Coats TJ, Duranteau J, Fernández-Mondéjar $\mathrm{E}$, et al. The European guideline on management of major bleeding and coagulopathy following trauma: fourth edition. Crit Care. 2016; 20:100. doi: http://dx.doi.org/10.1186/s13054-0161265-x

18. Arksey H, O'Malley L. Scoping studies: towards a methodological framework. International J Soc Res Methodol. 2005; 8(1):19-32. doi: http://dx.doi.org/ 10.1080/1364557032000119616.

19. Davis K, Drey N, Gould D. What are scoping studies? A review of the nursing literature. Int J Nurs Stud. 2009;
46(10):1386-400. doi: http://dx.doi.org/10.1016/j. ijnurstu.2009.02.010.

20. Rau CS, Wu SC, Kuo SCH, Kuo PJ, Hsu SY, Chen YC, et al. Prediction of massive transfusion in trauma patients with shock index, modified shock index, and age shock index. Int J Environ Res Public Health. 2016; 13(7):683. doi: http://dx.doi.org/10.3390/ijerph13070683.

21. Pottecher J, Ageron FX, Fauché C, Chemla D, Noll E, Duranteau J, et al. Prehospital shock index and pulse pressure/heart rate ratio to predict massive transfusion after severe trauma: Retrospective analysis of a large regional trauma database. J Trauma Acute Care Surg. 2016; 81(4):713-22. doi: http://dx.doi.org/10.1097/ TA.0000000000001191.

22. Ruchholtz S, Pehle B, Lewran U, Lefering R, Muller $N$, Oberbeck $R$, et al. The emergency room transfusion score (ETS): prediction of blood transfusion requirement in initial resuscitation after severe trauma. Transf Med. 2006; 16(1):49-56. doi: https://doi.org/10.1111/ j.1365-3148.2006.00647.x.

23. Kuhne CA, Zettl RP, Fischbacher $M$, Lefering $R$, Ruchholtz S. Emergency Transfusion Score (ETS): a useful instrument for prediction of blood transfusion requirement in severely injured patients. Wrld J Surg. 2008; 32(6):1183-8. doi: http://dx.doi.org/10.1007/ s00268-007-9425-4.

24. Yücel $N$, Lefering $R$, Maegele $M$, Vorweg $M$, Tjardes T, Ruchholtz S, et al. Trauma Associated Severe Hemorrhage (TASH)-Score: probability of mass transfusion as surrogate for life threatening hemorrhage after multiple trauma. J Trauma. 2006; 60(6):1228-36. doi: http://dx.doi.org/10.1097/01. ta.0000220386.84012.bf

25. Maegele $M$, Lefering $R$, Wafaisade $A$, Theodorou $P$, Wutzler $S$, Fischer $P$, et al. Revalidation and update of the TASH-Score: a scoring system to predict the probability for massive transfusion as a surrogate for lifethreatening haemorrhage after severe injury. Vox Sang. 2011; 100(2):231-8. doi: http://dx.doi.org/10.1111/ j.1423-0410.2010.01387.x.

26. Schreiber M, Perkins J, Kiraly L, Underwood S, Wade C, Holcomb JB. Early predictors of massive transfusion in combat casualties. J Am Coll Surg. 2007; 205(4):541-5. doi: http://dx.doi.org/10.1016/j. jamcollsurg.2007.05.007.

27. McLaughlin DF, Niles SE, Salinas J, Perkins JG, Cox ED, Wade CE, et al. A Predictive Model for Massive Transfusion in Combat Casualty Patients. J Trauma. 
2008; 64(2):57-63. doi: http://dx.doi.org/10.1097/ TA.0b013e318160a566.

28. Nunez TC, Voskresensky IV, Dossett LA, Shinall R, Dutton WD, Cotton BA. Early prediction of massive transfusion in trauma: simple as $A B C$ (assessment of blood consumption)? J Trauma. 2009; 66(2):346-52. doi: http://dx.doi.org/10.1097/TA.0b013e3181961c35. 29. Cotton BA, Dossett LA, Haut ER, Shafi S, Nunez TC, $\mathrm{Au} B K$, et al. Multicenter validation of a simplified score to predict massive transfusion in trauma. J Trauma. 2010; 69(1):33-9. doi: http://dx.doi.org/10.1097/ TA.0b013e3181e42411.

30. Larson CR, White CE, Spinella PC, Jones JA, Holcomb JB, Blackbourne LH, et al. Association of shock, coagulopathy, and initial vital signs with massive transfusion in combat casualties. J Trauma. 2010; 69(1):26-32. doi: http://dx.doi.org/10.1097/ TA.0b013e3181e423f4.

31. Vandromme MJ, Griffin RL, McGwin G, Weinberg J, Rue LW, Kerby JD. Prospective identification of patients at risk for massive transfusion: an imprecise endeavor. Am Surg. 2011; 77(2):155-61. doi: http://dx.doi. org/10.1097/TA.0b013e3182095a0a.

32. Rainer $\mathrm{TH}, \mathrm{Ho} A M H$, Yeung JHH, Cheung NK, Wong RSM, Tang N, et al. Early risk stratification of patients with major trauma requiring massive blood transfusion. Resuscitation. 2011; 82(6):724-9. doi: http://dx.doi. org/10.1016/j.resuscitation.2011.02.016.

33. Callcut RA, Johannigman JA, Kadon KS, Hanseman DJ, Robinson BR. All massive transfusion criteria are not created equal: defining the predictive value of individual transfusion triggers to better determine who benefits from blood. J Trauma. 2011; 70(4):794-801. doi: http:// dx.doi.org/10.1097/TA.0b013e3182127e40.

34. Callcut RA, Cotton BA, Muskat P, Fox EE, Wade CE, Holcomb JB, et al. Defining when to initiate massive transfusion (MT): a validation study of individual massive transfusion triggers in PROMMTT patients. J Trauma Acute Care Surg. 2013; 74(1):59-67. doi: http://dx.doi. org/10.1097/TA.0b013e3182788b34.

35. Callcut RA, Cripps MW, Nelson MF, Conroy AS, Robinson BB, Cohen MJ. The Massive Transfusion Score as a decision aid for resuscitation: Learning when to turn the massive transfusion protocol on and off. J Trauma Acute Care Surg. 2016; 80(3):450-6. doi: http://dx.doi. org/10.1097/TA.0000000000000914.

36. Ogura T, Nakamura Y, Nakano M, Izawa Y, Nakamura $M$, Fujizuka $K$, et al. Predicting the need for massive transfusion in trauma patients: the Traumatic Bleeding
Severity Score. J Trauma Acute Care Surg. 2014; 76(5):1243-50. doi: http://dx.doi.org/10.1097/ TA.0000000000000200.

37. Ogura T, Lefor AK, Masuda M, Kushimoto S. Modified traumatic bleeding severity score: Early determination of the need for massive transfusion. Am J Emerg Med. 2016; 34(6):1097-101. doi: http://dx.doi.org/10.1016/j. ajem.2016.02.072.

38. Cantle PM, Cotton BA. Prediction of Massive Transfusion in Trauma. Crit Care Clin. 2017; 33(1):7184. doi: http://dx.doi.org/10.1016/j.ccc.2016.08.002. 39. Brockamp T, Nienaber $U$, Mutschler M, Wafaisade $A$, Peiniger $S$, Lefering $R$, et al. Predicting on-going hemorrhage and transfusion requirement after severe trauma: a validation of six scoring systems and algorithms on the Trauma Register DGU. Crit Care. 2012; 16(4):R129. doi: http://dx.doi.org/10.1186/cc11432. 40. Nakamuraa $Y$, Ishikuraa $H$, Kushimotob $S$, Kiyomic F, Katod $\mathrm{H}$, Sasakie J, et al. Fibrinogen level on admission is a predictor for massive transfusion in patients with severe blunt trauma: Analyses of a retrospective multicentre observational study. Injury. 2017; 48(3):674-9. doi: http://dx.doi.org/10.1016/j. injury.2017.01.031.

41. Parimi MN, Hu PF, Mackenzie CF, Yang S, Bartlett ST, Scalea TM, et al. Automated continuous vital signs predict use of uncrossed matched blood and massive transfusion following trauma. J Trauma Acute Care Surg. 2016; 80(6):897-906. doi: http://dx.doi.org/10.1097/ TA.0000000000001047.

42. Chang R, Holcomb JB. Implementation of massive transfusion protocols in the United States: the relationship between evidence and practice. Int Anesth Res Soc. 2017; 124(1):9-11. doi: http://dx.doi. org/10.1213/ANE.0000000000001731.

43. Chang R, Holcomb JB. Optimal fluid therapy for traumatic hemorrhagic shock. Crit Care Clin 2017; 33(1):15-36. doi: http://dx.doi.org/10.1016/j. ccc.2016.08.007.

44. McDaniel LM, Etchill EW, Raval JS, Neal MD. State of the art: massive transfusion. Transf Med. 2014; 24(1):138-44. doi: http://dx.doi.org/10.1111/ tme.12125.

45. Ruseckaite R, McQuilten ZK, Oldroyd JC, Richter TH, Cameron PA, Isbister JP, et al. Descriptive characteristics and in-hospital mortality of critically bleeding patients requiring massive transfusion: results from the Australian and New Zealand Massive Transfusion Registry. Vox 
Sanguinis. 2017; 112(3):240-8. doi: http://dx.doi. org/10.1111/vox.12487.

46. Cohen MJ, Kutcher M, Redick B, Nelson M, Call M, Knudson MM, et al. Clinical and Mechanistic Drivers of Acute Traumatic Coagulopathy. J Trauma Acute Care Surg. 2013; 75(1S1): S40-7. doi: http://dx.doi. org/10.1097/TA.0b013e31828fa43d.

47. Burman S, Cotton BA. Trauma patients at risk for massive transfusion: the role of scoring systems and the impact of early identification on patients outcomes. Expert Rev Hematol. 2012; 5(2):211-8. doi: http:// dx.doi.org/10.1586/ehm.11.85.

48. Zielinski MD, Wilson GA, Johnson PM, Polites SF, Jenkins DH, Harmsen WS, et al. Ideal hemoglobin transfusion target for resuscitation of massivetransfusion patients. Surgery. 2016; 160(6):1560-7. doi: http://dx.doi.org/10.1016/j.surg.2016.05.022.

49. Umemura T, Nakamura Y, Nishida1 T, Hoshino $\mathrm{K}$, Ishikura H. Fibrinogen and base excess levels as predictive markers of the need for massive blood transfusion after blunt trauma. Surg Today. 2016; 46(7):774-9. doi: http://dx.doi.org/10.1007/s00595015-1263-7.

50. Shackelford S, Yang S, Hu P, Miller C, Anazodo A, Galvagno $S$, et al. Predicting blood transfusion using automated analysis of pulse oximetry signals and laboratory values. J Trauma Acute Care Surg. 2015; 79(4S2):S175-80. doi: http://dx.doi.org/10.1097/ TA.0000000000000738.

51. Smith SA, Livingston MH, Merritt NH. Early coagulopathy and metabolic acidosis predict transfusion of packed red blood cells in pediatric trauma patients. J Pediatr Surg. 2016; 51(5):848-52. doi: http://dx.doi. org/10.1016/j.jpedsurg.2016.02.034.

52. Holcomb JB, del Junco D, Fox EE, Wade CE, Cohen M, Schreiber MJ, et al. The Prospective, Observational, Multicenter, Major Trauma Transfusion (PROMMTT) Study: Comparative Effectiveness of a Time-varying Treatment with Competing Risks. JAMA Surg. 2013; 148(2):127-36. doi: http://dx.doi.org/10.1001/2013. jamasurg. 387.

53. Ishikura $H$, Kitamura $T$. Trauma-induced coagulopathy and critical bleeding: the role of plasma and platelet transfusion. J Intensive Care; 2017; 5:2. doi: http://dx.doi.org/10.1186/s40560-016-0203-y. 54. Cannon JW, Khan MA, Raja AS, Cohen MJ, Como $\mathrm{J}$, Cotton BA, et al. Damage control resuscitation in patients with severe traumatic hemorrhage: A practice management guideline from the Eastern Association for the Surgery of Trauma. J Trauma Acute Care Surg. 2017; 82(3):605-17. doi: http://dx.doi.org/10.1097/ TA.0000000000001333.
Received: Dec $15^{\text {th }} 2017$ Accepted: Oct $8^{\text {ht }} 2018$
Copyright $\odot 2018$ Revista Latino-Americana de Enfermagem This is an Open Access article distributed under the terms of the Creative Commons (CC BY).

This license lets others distribute, remix, tweak, and build upon your work, even commercially, as long as they credit you for the original creation. This is the most accommodating of licenses offered. Recommended for maximum dissemination and use of licensed materials. 